DOI: 10.17707/AgricultForest.63.1.19

\author{
Jasmina Balijagić, Jelena Bošković, \\ Jovan CRNOBARAC, Veselinka ZEČEVIĆ, \\ Dragoja RADANOVIĆ, Gordana DOZET, Miodrag JOVANČEVIĆ ${ }^{I}$

\section{MORPHO - PHYSIOLOGICAL CHARACTERISTICS OF GENTIAN (Gentiana lutea L.) GENOTYPE SEEDLINGS FROM NATURAL POPULATIONS IN MONTENEGRO}

\begin{abstract}
SUMMARY
The aim of this paper is to examine the possibility of gentian generative propagation, because the production of high-quality planting material is very important not only for the beginning of revitalization of this plant species in their natural habitat but also for its large-scale production in Montenegro. Cultivation of gentian, as well as other medicinal plants, represents a safe way for their protection and conservation in the wild. For the purpose of choosing the best population, seed samples from 9 natural habitats were collected in the mountains of the northern part of Montenegro. The field trial in which dynamics of gentian seedlings growth was monitored in the first and the second year of vegetation was set up by sowing of seeds collected in natural conditions at the locality Korita.

The average fresh root weight of the sowed annual seeds was $0.17 \mathrm{~g}$ and the maximum weight had seedlings originating from the locality called Jovanova koliba. The average dry matter content in the roots was $29.18 \%$. The average root length of biennial seedlings of the tested population was $14.6 \mathrm{~cm}$ and maximum length had seedlings originating from Prelija. The average root fresh weight of the analyzed population of biennial seedlings was $0.96 \mathrm{~g}$ and maximum weight had seedlings from Jovanova koliba $(1.57 \mathrm{~g})$.
\end{abstract}

Keywords: Gentiana lutea, natural populations, seedling, root

\title{
INTRODUCTION
}

Gentian lutea L. (yellow, big gentian or Gentianella austriaca) is a perennial, heliophilous, herbaceous rugged mountain plant of wide ecological valence. Its habitats are spread across the Alps, the Apennines, the Carpathian mountains, the Iberian and the Balkan Peninsula (Hesse et al., 2007; Vender et al., 2010) 300-2800 $\mathrm{m}$ above sea level, on different soil types, which as a rule

\footnotetext{
${ }^{1}$ Jasmina Balijagić (correspondging author: jas.be@t-com.me), Miodrag Jovančević University of Montenegro, Biotechnical Faculty, Podgorica, MONTENEGRO, Jelena Bpšković Business Academy University in Novi Sad, Faculty of Economics and Engineering Management, Novi Sad, SERBIA, Jovan CRNOBARAC University of Novi Sad, Faculty of Agriculture, Novi Sad, SERBIA, Veselina Zečević, Gordana Dozet John Naisbitt University Belgrade, Faculty of Biofarming in Bačka Topola, SERBIA, Dragoja Radanović Institute for Medicinal Plant Research "Dr. Josif Pančić" Belgrade, SERBIA

Notes: The authors declare that they have no conflicts of interest. Authorship Form signed online.
} 
contain more than $6 \%$ of humus (Stepanović and Radanović, 2011). Gentian is more or less found on almost all Montenegrin mountains: Sinjajevina, Bjelasica, Prokletije (Plav-Gusinje), Hajla, Komovi, Durmitor, Ljubišnja, Morača Mountains, Orjen, Lovcen, Rumija, Volujak, Vojnik, Golija, in the plateau of Korita as well as in Štedim (Balijagić et al., 2012a; 2012b).

The demand for gentian use in herbal medicine and the beverage industry has been growing steadily (Sezik et al., 2005; Kušar and Baričević, 2006; Balijagić et al., 2012a; 2012b). Only in Europe, 400-500 tons of dry root (Radanović et al., 2014) is consumed annually. Thus, large amounts of yellow gentian root cannot be collected from natural populations over a longer period of time without the risk of its destruction. In almost all countries, yellow gentian is under a regime of strict control against exploitation, and in most countries of South Eastern Europe its use from natural populations is prohibited (Radanović et al., 2014).

In the last century, irrational exploitation of gentian caused its eradication or great reduction in most of our mountains. Sustainable use of natural resources can only be achieved with the introduction of plants, as well as cultivation, which is an important way to protect endangered plant species (Menges, 2000). Therefore, in recent decades of the last and at the beginning of this century, abroad, but also in Serbia and Slovenia great efforts had been made to develop a technology for gentian cultivation, especially in rural mountainous areas (Kušar and Baričević, 2006; Radanović et al., 2007b; 2007c; Radanović, 2008; Franz, 2012; Radanović et al., 2013; 2014; Balijagić, 2013; González-López et al., 2014; Sand, 2015).

The aim of this study was to examine the possibility of reproduction of gentian seeds and choose the most suitable populations of plant species in agricultural conditions of Montenegro. The production of high-quality planting material is very important for the start of the revitalization of plant species in their natural habitats as well as for their large-scale production in Montenegro. The cultivation of gentian as well as other medicinal plant species represents a safe way for protection and conservation of wild plants whose survival is endangered due to overexploitation. Besides that, the cultivation of endangered species has an important socio-economic dimension, as it can enable the rural development of the impoverished population in mountain regions.

\section{MATERIAL AND METHODS}

In 2009, the gentian seeds were collected from nine natural habitats in the mountains of northern part of Montenegro that are located at altitudes from 1.400 to $2.076 \mathrm{~m}$ (Table1). The seeds were collected in accordance with the Law on Environmental Protection. Parts of collected inflorescence were dried in the shade, in the drafty place to air dry state, followed by manual threshing of seeds.

The same year, the field trial was set up under natural conditions at the locality of Korita (Sušica), which is at an altitude of $1.300 \mathrm{~m}$ and has good soil conditions for gentian cultivation (Table 2). 
Table 1. Localities where in 2009 the seeds of yellow gentian were collected, the mountains in northern part of Montenegro

\begin{tabular}{|c|c|c|c|c|}
\hline \multicolumn{2}{|c|}{ Population } & $\begin{array}{c}\text { Number of } \\
\text { plants } \\
\text { (average) }\end{array}$ & $\begin{array}{c}\text { The average } \\
\text { fresh root (g) } \\
\text { mass }\end{array}$ & $\begin{array}{c}\text { The average } \\
\text { dry root }(\mathrm{g}) \\
\text { mass }\end{array}$ \\
\hline \multicolumn{2}{|l|}{ Strmenica } & 24.00 & 0.178 & 0.051 \\
\hline \multicolumn{2}{|c|}{ Kobilja glava } & 24.50 & 0.138 & 0.038 \\
\hline \multicolumn{2}{|l|}{ Durmitor } & 22.25 & 0.277 & 0.075 \\
\hline \multicolumn{2}{|l|}{ Gutavica } & 31.25 & 0.095 & 0.033 \\
\hline \multicolumn{2}{|c|}{ Konjska rijeka } & 15.50 & 0.123 & 0.037 \\
\hline \multicolumn{2}{|c|}{ Prošćen Mountains } & 16.50 & 0.111 & 0.029 \\
\hline \multicolumn{2}{|l|}{ Prelija } & 13.50 & 0.142 & 0.043 \\
\hline \multicolumn{2}{|c|}{ Jovanova koliba } & 17.50 & 0.301 & 0.088 \\
\hline \multicolumn{2}{|l|}{ Ljubišnja } & 16.00 & 0.164 & 0.048 \\
\hline \multicolumn{2}{|l|}{ Average } & 20.11 & 0.170 & 0.049 \\
\hline \multirow{2}{*}{ LSD } & $1 \%$ & - & 0.131 & 0.039 \\
\hline & $5 \%$ & - & 0.097 & 0.029 \\
\hline \multicolumn{3}{|c|}{$\mathrm{F}-$ probability $(\mathrm{p})$} & 0.001 & 0.003 \\
\hline
\end{tabular}

During September 2009, the sowing in the field trial was conducted in already prepared beds, according to the method of non-hormonal production of gentian seedlings in open winter beds (Radanović et al., 2007b).

According to the agrochemical analyses of the soil (Table 2), the farmyard manure was added to the soil before planting, at a dose of $100 \mathrm{~m}^{3} \mathrm{ha}^{-1}$ and mineral fertilizer NPK (8:20:30) at a dose of $150 \mathrm{~kg} \mathrm{ha}^{-1}$. The basic agrochemical analyses of the soil are determined by standard methods prescribed for soil analysis. Weed control in experimental plots was performed manually by hoeing and weeding, and during the summer beds were semi-shaded by a protective net. The field trial was irrigated as needed.

Table 2. Agrochemical soil analyses $(0-30 \mathrm{~cm})$ from the localities where the trial was set up

\begin{tabular}{|c|c|c|c|c|c|c|}
\hline \multirow{2}{*}{$\begin{array}{c}\text { Number of } \\
\text { samples }\end{array}$} & \multicolumn{2}{|c|}{ pH } & \multirow{2}{*}{$\begin{array}{c}\mathrm{CaCO}_{3} \\
(\%)\end{array}$} & \multirow{2}{*}{$\begin{array}{c}\text { Humus } \\
(\%)\end{array}$} & $\mathbf{P}_{2} \mathbf{O}_{5}$ & $\mathrm{~K}_{2} \mathrm{O}$ \\
\hline & $\mathrm{u} \mathrm{H}_{2} \mathrm{O}$ & $\mathrm{u} \mathrm{KCl}$ & & & \multicolumn{2}{|c|}{$\mathrm{mg} / 100 \mathrm{~g}$ of soil } \\
\hline 1 & 6.43 & 5.85 & 2.8 & 4.81 & 2.2 & 11.5 \\
\hline 2 & 6.17 & 5.60 & 2.6 & 4.48 & 2.6 & 10.4 \\
\hline
\end{tabular}

For each of the studied population, four furrows (4 replications) were formed in beds, and each was sown by 250 seeds. At the end of the first year of vegetation, from each furrow, in four replications, at row length of $15 \mathrm{~cm}$, the seedlings were removed. Firstly, the number of seedlings was determined, and this was followed by measurements of roots' neck width, roots' length, roots' 
mass per seedling, as well as dry matter content in the root of seedling. The same measurements were also performed at the end of the second vegetation period.

The weight of plant was measured by precise laboratory beam scale while the length and thickness of seedlings' parts were measured by a vernier caliper.

Statistical data processing included a factorial analysis of variance and the averages of treatments were compared by LSD test (Witte and Witte, 2013) and a standard deviation (SD) was calculated as a measure of variation.

\section{RESULTS AND DISCUSSION}

\section{Morpho-physiological characteristics of the annual seedlings}

The average number of plants in analyzed samples of all populations was 20.11. The minimum number of plants (13.50) belonged to the population originating from locality Prelija locality while the maximum (31.25) from the locality called Gutavica (Table 3).

Table 3. The number of the studied plants and morho-physiological characteristics of the annual seedlings

\begin{tabular}{|c|c|c|c|c|}
\hline \multicolumn{2}{|c|}{ Population } & $\begin{array}{c}\text { Number of } \\
\text { plants } \\
\text { (average) }\end{array}$ & $\begin{array}{c}\text { The average } \\
\text { fresh root }(\mathrm{g}) \\
\text { mass } \\
\end{array}$ & $\begin{array}{c}\text { The average } \\
\text { dry root (g) } \\
\text { mass }\end{array}$ \\
\hline \multicolumn{2}{|l|}{ Strmenica } & 24.00 & 0.178 & 0.051 \\
\hline \multicolumn{2}{|c|}{ Kobilja glava } & 24.50 & 0.138 & 0.038 \\
\hline \multicolumn{2}{|l|}{ Durmitor } & 22.25 & 0.277 & 0.075 \\
\hline \multicolumn{2}{|l|}{ Gutavica } & 31.25 & 0.095 & 0.033 \\
\hline \multicolumn{2}{|c|}{ Konjska rijeka } & 15.50 & 0.123 & 0.037 \\
\hline \multicolumn{2}{|c|}{ Prošćen Mountains } & 16.50 & 0.111 & 0.029 \\
\hline \multicolumn{2}{|l|}{ Prelija } & 13.50 & 0.142 & 0.043 \\
\hline \multicolumn{2}{|c|}{ Jovanova koliba } & 17.50 & 0.301 & 0.088 \\
\hline \multicolumn{2}{|l|}{ Ljubišnja } & 16.00 & 0.164 & 0.048 \\
\hline \multicolumn{2}{|l|}{ Average } & 20.11 & 0.170 & 0.049 \\
\hline \multirow{2}{*}{ LSD } & $1 \%$ & - & 0.131 & 0.039 \\
\hline & $5 \%$ & - & 0.097 & 0.029 \\
\hline \multicolumn{2}{|c|}{$\mathrm{F}-$ probability $(\mathrm{p})$} & & 0.001 & 0.003 \\
\hline
\end{tabular}

The average fresh root weight of the annual seedlings was $0.170 \mathrm{~g}$. The minimum average fresh root weight $(0.095 \mathrm{~g})$ was recorded on plants from locality Gutavica, while the maximum $(0.301 \mathrm{~g})$ on gentian seedlings from locality Jovanova koliba. F-test of variance analysis (0.001) shows that the localities had significant effect on the fresh root weight of annual seedlings (Table 3).

The average weight of air dried roots in all seedlings was $0.049 \mathrm{~g}$. The minimum weight $(0.029 \mathrm{~g})$ of air dried roots had the plants obtained by sowing 
seeds of natural populations from the locality called Prošćen mountains and the maximum $(0.088 \mathrm{~g})$ from the locality called Jovanova koliba. F-test of variance analysis (0.003) shows that the localities had a significant effect on the mass of air dried roots (Table 3 ). The values of annual seedling mass were significantly lower in comparison to those obtained in the study of RADANOVIĆ et al. (2013), in which at the end of the first growing season in Serbia the average seedling fresh mass of gentian was $1.79 \mathrm{~g}$. These differences are presumably caused by high quality seeds obtained by cultivated gentian, as well as by better conditions in seed beds seedlings' production in Serbia.

\section{Morpho- physiological characteristics of biennial seedlings}

The average number of plants of biennial seedlings in the studied samples of yellow gentian was 28.3. The maximum number of plants (42.0) was obtained from the seeds originating from the natural population of Durmitor locality and the minimum (15.3) from seeds of Prošćen mountains. F-test of variance analysis shows that localities had no significant effect on the number of plants (Table 4). Previous experiences in cultivation of yellow gentian obtained in the southern and South-eastern Europe demonstrated that the climatic conditions and the slow rooting and development of seedlings in the first two years of cultivation are the main limiting factors which cause great losses of plants and thus the low root yield (RADANOVIĆ et al., 2014).

Table 4: The number of the studied morpho - physiological characteristics of biennial seedlings

\begin{tabular}{|c|c|c|c|c|c|}
\hline Population & $\begin{array}{l}\text { Number of plants } \\
\text { (average) }\end{array}$ & $\begin{array}{c}\text { The } \\
\text { average } \\
\text { root } \\
\text { neck } \\
\text { widht } \\
(\mathrm{mm})\end{array}$ & $\begin{array}{l}\text { The } \\
\text { average } \\
\text { root } \\
\text { length } \\
(\mathrm{cm})\end{array}$ & $\begin{array}{l}\text { The } \\
\text { average } \\
\text { fresh } \\
\text { root } \\
\text { mass } \\
\text { (g) }\end{array}$ & $\begin{array}{l}\text { The } \\
\text { average } \\
\text { dry root } \\
\text { mass (g) }\end{array}$ \\
\hline Strmenica & 16.8 & 3.0 & 12.2 & 0.57 & 0.17 \\
\hline Kobilja glava & 33.3 & 3.3 & 15.8 & 0.67 & 0.20 \\
\hline Durmitor & 42.0 & 4.2 & 14.0 & 1.01 & 0.29 \\
\hline Gutavica & 29.3 & 4.4 & 15.5 & 1.29 & 0.35 \\
\hline Konjska rijeka & 28.8 & 3.5 & 13.3 & 0.72 & 0.19 \\
\hline $\begin{array}{l}\text { Prošćen } \\
\text { mountains }\end{array}$ & 15.3 & 3.0 & 13.5 & 0.48 & 0.28 \\
\hline Prelija & 30.0 & 4.0 & 16.2 & 1.10 & 0.13 \\
\hline Jovanova koliba & 17.5 & 4.8 & 15.4 & 1.57 & 0.24 \\
\hline Ljubišnja & 41.8 & 4.1 & 15.7 & 1,23 & 0.41 \\
\hline Average & 28.3 & 3.8 & 14.6 & 0.96 & 0.25 \\
\hline \multirow{2}{*}{ LSD } & 30.27 & 1.0 & 4.0 & 0.71 & 0.15 \\
\hline & 22.33 & 0.8 & 2.9 & 0.52 & 0.11 \\
\hline F - probability & 0.14 & $<.001$ & 0.103 & 0.003 & $<.001$ \\
\hline
\end{tabular}


The average width - roots' neck diameter of the examined populations was $3.8 \mathrm{~mm}$. The minimum average diameter of $3.0 \mathrm{~mm}$ had seedlings originating from locality Strmenica and the maximum of $4.8 \mathrm{~mm}$ seedlings produced from the seeds of Jovanova koliba locality. F-test of variance analysis (<.001) shows that localities had significant effect on the diameter of the root neck of biennial gentian seedlings (Table 4)

The average value of the standard deviation (SD) for the width of the root neck for nine populations of the studied seedlings was $1.26 \mathrm{~mm}$ (Table 5). The minimum Sd value of 1.04 was obtained from seedlings originating from seeds from locality Durmitor and the maximum (1.81) from seedlings obtained from seeds from locality Jovanova koliba.

For nine populations, the average value of the coefficient of variation $(\mathrm{CV})$ width of roots' neck was 33. 44\%. The lowest coefficient of variation (24.81) was between seedlings from Durmitor locality and the highest (43.96) from locality Strmenica. Individually, the smallest root neck width of a biennial gentian $(0.90 \mathrm{~mm})$ was recorded in seedlings from locality Prelija and the highest $(9.90 \mathrm{~mm})$ in seedlings obtained from seeds of Gutavica locality. The obtained values of the width of root neck of biennial seedlings in this trial are lower in comparison to those obtained in the study of RADANOVIĆ et al. (2013) who at the end of the second year of growing obtained plants with average diameter of roots' neck of $13.03 \mathrm{~mm}$. The plants were grown out of cultivated gentian seeds from Serbia.

Table 5: Indicators of biennial seedlings variability of root neck width

\begin{tabular}{|c|c|c|c|c|}
\hline Population & SD $(\mathrm{mm})$ & $\mathrm{CV}(\%)$ & $\min$ & $\max$ \\
\hline For all 9 population & 1.26 & 33.44 & 0.90 & 9.90 \\
\hline
\end{tabular}

The average root length of the studied populations was $14.6 \mathrm{~cm}$. The minimum average root length $(12.2 \mathrm{~cm})$ had seedlings originating from Strmenica locality and the maximum $(16.2 \mathrm{~cm})$ had seedlings originating from Prelija locality. F-test analysis of variance $(0,103)$ shows that the localities had no significant effect on the root length (Table 4).

The average value of SD for root length for nine populations was 4.98 (Table 6). The minimum value (3.35) was recorded in seedlings from locality Jovanova koliba, and the maximum (14.53) in seedlings from locality Kobilja glava. The average value of the coefficient of variation between root lengths (CV) in the examined population was 33.67.

The highest coefficient of variation (91.91) in root length had the seedlings of the population from locality Kobilja glava, and the smallest (20.75), the seedlings of the population from locality Jovanova koliba. The minimum root length $(4.50 \mathrm{~cm})$ measured separately, had seedlings obtained from the seeds of locality Prelija, and the maximum $(30.80 \mathrm{~cm})$ seedlings of the population from locality Durmitor. 
Table 6: Indicators of biennial seedlings' variability of root length

\begin{tabular}{|l|c|c|c|c|}
\hline Population & SD $(\mathrm{cm})$ & CV $(\%)$ & $\min$ & $\max$ \\
\hline Strmenica & 4.29 & 34,98 & 4.70 & 21.30 \\
\hline Kobilja glava & 14.53 & 91,91 & 7.1 & 23.30 \\
\hline Durmitor & 4.04 & 28.94 & 6.30 & 30.80 \\
\hline Gutavica & 3.75 & 24.18 & 7.50 & 24,80 \\
\hline Konjska rijeka & 3.51 & 26.28 & 7.60 & 26.90 \\
\hline Prošćen mountains & 3.90 & 24.89 & 8.30 & 24.50 \\
\hline Prelija & 3.55 & 26.25 & 4.50 & 20.50 \\
\hline Jovanova koliba & 3.35 & 20.75 & 9.50 & 24.70 \\
\hline Ljubišnja & 3.93 & 24.85 & 5.40 & 24.00 \\
\hline For all 9 population & 4.98 & 33.67 & 4.50 & 24.8 \\
\hline
\end{tabular}

The average value of the fresh root mass of biennial seedlings was $0.96 \mathrm{~g}$. The minimum average mass $(0.48 \mathrm{~g})$ had seedlings obtained from seeds from locality Prošćen mountains, and the maximum $(1.57 \mathrm{~g})$ had seedlings of the population from locality Jovanova koliba. F-test analysis of variance $(<.001)$ shows that localities had significant effect on fresh root mass (Table 4).

The average value of standard deviation of the examined biennial seedlings' fresh root mass was 0.85 (Table 7). The minimum value of SD (0.44) was recorded in seedlings of the population from locality Prelija and the maximum (1.42) had seedlings of the population from Ljubišnja locality. Coefficient of variation value (CV) for the studied population fresh root weight was $92.21 \%$. A minimum variation of fresh root weight $(59.33 \%)$ was within the population of locality Durmitor and a maximum (124.58\%) had seedlings from locality Konjska Rijeka. The minimum mass obtained by the separate measurement of seedlings fresh root weight $(0.02 \mathrm{~g})$ had seedlings from locality Prelija and the maximum ( $8.42 \mathrm{~g})$ had seedlings of the population from locality Gutavica.

Table 7. Indicators of biennial seedlings' variability of fresh roots mass

\begin{tabular}{|c|c|c|c|c|}
\hline Population & $\mathrm{SD}(\mathrm{g})$ & $\mathrm{CV}(\%)$ & $\min$ & $\max$ \\
\hline Strmenica & 0.62 & 112.8 & 0.04 & 2.49 \\
\hline Kobilja glava & 0.69 & 102.01 & 0.08 & 3.59 \\
\hline Durmitor & 0.60 & 59.33 & 0.17 & 3.34 \\
\hline Gutavica & 1.30 & 101.14 & 0.16 & 8.49 \\
\hline Konjska rijeka & 0.90 & 124.58 & 0.15 & 4.85 \\
\hline Prošćen mountains & 0.81 & 66.08 & 0.28 & 4.07 \\
\hline Prelija & 0.44 & 91.86 & 0.02 & 1.69 \\
\hline Jovanova koliba & 0.88 & 80.25 & 0.10 & 4.20 \\
\hline Ljubišnja & 1.42 & 91.87 & 0.12 & 6.79 \\
\hline For all 9 population & 0.85 & 92.21 & 0.02 & 8.49 \\
\hline
\end{tabular}


The average of air dried root mass of the studied populations was $0.25 \mathrm{~g}$. The minimum average mass had seedlings obtained from seeds collected in Prelija locality $(0.13 \mathrm{~g})$ while the maximum mass had seedlings from mountain Ljubišnja (0.41). F-test analysis of variance $(<.001)$ shows that localities had a significant effect on air dried root mass of seedlings (Table 4).

The average root length of biennial seedlings was $14.6 \mathrm{~cm}$. F-test analysis of variance indicates that the localities did not affect seedlings root length. Our results are in accordance with the statements of Radanovic et al. (2007a): the length of annual seedlings in September were about $10 \mathrm{~cm}$ because there was a great probability that root of annual seedlings would grow for $1.25 \mathrm{~cm}$ more by October, the time when the measurements were performed.

In the third year of gentian cultivation in the pots, Galambosi and Galambosi (2010) achieved the one plant root yield of $78 \mathrm{~g}$ with 3 plants per pot, up to $44.3 \mathrm{~g}$ with 10 plants per pot.Our studies also confirmed that higher seedling number and density per unit of area reduce weight of seedlings root.

\section{CONCLUSIONS}

The origin of seeds i.e. the population had a significant effect on annual and biennial seedlings fresh and dry root mass, as well as on the width of roots' neck, while the origin of seeds had no significant effect on the relation between fresh and dry root mass, as well as on the length of both kinds of seedlings.

The population of seeds from the locality called Jovanova koliba should be used for the production of gentian seedlings. That seed had the highest average fresh root yield in both, annual and biennial seedlings with the lower coefficient of variance for this trait in comparison with the average value for all populations. Along with the gained experience in cultivation, this population would provide the best results in the production of gentian seedlings.

\section{ACKNOWLEDGEMENTS}

We would like to express the deepest gratitude to the Ministry of Education and Science of Montenegro for the financial support of three- year scientific research project "The examination of the possibility for gentian seedling production as well as the environmental and biodiversity protection" (No. 06/3-2302/7).

\section{REFERENCES}

Balijagić, J., T. Janković, G. Zdunić, J. Bošković, K. Šavikin, D. Godevac, T. Stanojković, M. Jovančeić, N. Menković (2012a): Chemical profile, radical, seevenging and cytotoxic activity of yelow Gentian leaves (Gentitaneae luteae folium) grown in Northern Regions of Montenegro. Natural Product Communications, 7 (11): 1487-1490.

Balijagić, J., D. Radanović, S. Antic Mladenović, J. Crnobarac, J. Bošković, V. Zečević, G. Dozet, M. Jovančević (2012b): Mineral content of autochthonous gentian (Gentiana lutea L.) root from natural habitats in northern parts of Montenegro. In Dajić-Stevanović Z. and D. Radanović (Eds). Proceedings of the seventh conference on medicinal and aromatic plants of Southeast European countries, Subotica, May $27^{\text {th }}-31^{\text {st }}, 2012$, pp. $255-264$. 
Balijagić, J. (2013): Populations of yellow gentian (Gentiana lutea L.) in the northern part of Montenegro and possibilities of growing. (in Serbian). PhD. thesis, Megatrend University Belgrade, Faculty of Biofarming Backa Topola, Serbia, pp. 1-108.

Franz, CH. (2012): Enzian, Gelber (Gentiana lutea L.). In: Handbuch des Arznei-und Gewürzpflanzenanbaus, Band 4, Arznei-und Gewürzpflanzen A-K, Verein fur Arznei-und Gewürzpflanzen Saluplanta e.V. Bernburg, pp. 375-385.

Galambosi, B., Z.S. Galambosi (2010): Seedling quality and seed yield of Gentiana lutea L. Acta Hortic. 860, 255-258. http://dx.doi.org/10.17660/ActaHortic.2010.860.38

González-López, Ó., P.A. Casquero (2014): Effects of $\mathrm{GA}_{3}$ pregerminative treatment on Gentiana lutea L. var. aurantiaca. Germination and seedlings morphology. The Scientific World Journal, vol. 2014: 1-6. http://dx.doi.org/10.1155/2014/751279

Hesse, E., M. Rees, H. Müller-Schärer (2007): Seed bank persistence of clonal weeds in contrasting habitats: implications for control. Plant Ecol., 190: 233-243.

Kušar, A., D. Baričević (2006): Cultivation trials of yellow gentian (Gentiana lutea L. subsp. Symphyandra Murb.) in west part of Slovenia. Acta Agriculturae Slovenica, 87: 213-22.

Menges, C.E. (2000): Population viability analyses in plants: challenges and opportunities. Trends Ecol Evol. 15: 51-56.

Radanović, D., T. Marković, T. Janković (2007a): Morphological and chemical parameters of importance for cultivation of Gentiana lutea L. in mountain region of Serbia, $1^{\text {st }}$ International scientific conference on medicinal, aromatic and spice plants, Nitra, Slovakia, December 5-6, 2007, Book of scientific papers, 28-32.

Radanović, D., T. Marković, B. Spasojević (2007b): Without the hormone production process of seedlings of yellow gentian (Gentiana lutea L.) in open seed beds. (in Serbian). The technical solution, Institute for Medicinal Plant Research "Dr. Josif Pančić" Belgrade, 1-16.

Radanović, D., S. Antić Mladenović, M. Jakovljević, M. Kresović (2007c): Content of heavy metals in Gentiana lutea L. roots and galenic forms. J. Serb. Chem, Soc. 72 (2): 133-138.

Radanović, D. (2008): New advances in the cultivation of yellow gentian (Gentiana lutea) and arnica (Arnica montana) in Serbia. (in Serbian). Plenary lecture, XXVIII Conference on medicinal and aromatic plants, Section for medicinal plants, Vršac, 8-11. 10. 2008, Proceedings, 12-18.

Radanović, D., T. Marković, S. Antić Mladenović (2013): Production of yellow gentian (Gentiana lutea L.) nursery plants suitable for transplanting and cultivation under dry farming conditions in mountain region of Serbia. Ratar.Povrt. 50 (3): 13-21.

Radanović, D., T. Marković, N. Aielo, P. Fusani (2014): Cultivation trials on Gentiana lutea L. in Southern and South-eastern Europe. Journal of Applied Research on Medicinal and Aromatic Plants, 1(4):113-122.

Sand, S.C. (2015): Peculiarities for agricultural techonolgy of gentiana lutea. Scientific Papers Series Management, Economic Engineering in Agriculture and Rural Development, 15, (1): 449-454.

Stepanović, B., D. Radanović (2011): The technology of cultivation of medicinal and aromatic plants in Serbia. (in Serbian). Institute for Medicinal Plant Research "Dr. Josif Pančić" Belgrade, pp. 1-243.

Vender, C., N. Aiello, S. Piovesana (2010): Survey of yellow gentiana populations of the Central Alps and record of their main morphological and qualitative $\begin{array}{llll}\text { characteristics. } & \text { Acta } & \text { Hortic. } & \text { 860, }\end{array}$ http://dx.doi.org/10.17660/ActaHortic.2010.860.13.

Witte, S.R., J.S. Witte (2013): Statistics, 10 ${ }^{\text {th }}$ Edition. Publisher: Wiley, ISBN-13: 9781118450536. P. 576. 